\title{
SERUM GLYCOMARKERS OF ENDOPLASMIC RETICULUM AND LYSOSOMAL-ENDOSOMAL SYSTEM STRESS IN HUMAN HEALTHY AGING AND DISEASES
}

\author{
I. U. PISMENETSKAYA', T. D. BUTTERS ${ }^{2}$ \\ ${ }^{1}$ SI Dnepropetrovsk Medical Academy, Ukraine; \\ ${ }^{2}$ CarboNet Consulting Ltd., Oxford, UK \\ e-mail: ip01589@gmail.com
}

To verify the idea that extracellular free oligosaccharides might be able to reflect the functional status of the endoplasmic reticulum (ER) and lysosomal-endosomal system, HPLC-profiles of serum-derived free oligosaccharides (FOS) in human healthy aging, acute myeloproliferative neoplasms, and cardiovascular pathologies were compared with intracellular glycans. After plasma deproteinization and FOS purification the oligosaccharides were labelled with anthranilic acid, separated into the neutral and charged with QAE Sephadex (Q25-120) chromatography and analysed using high-performance liquid chromatography (HPLC). The charged FOS were digested with a sialidase and compared with free oligosaccharides from transferrin for structural decoding. HPLC-profiles of serum-derived FOS revealed mild delay of the dolichol phosphate cycle in ER, moderate intensification of ER-associated degradation (ERAD) and degradation in endosomallysosomal system with aging; an inhibition of the dolichol phosphate cycle, intensification of ERAD and increasing of lysosomal exocytosis in acute myeloproliferative neoplasms; intensification of ERAD and glycocojugate degradation with endosomal-lysosomal system in cardiovascular diseases. As serum free oligosaccharides are able to reflect specifically perturbations in ER and endosomal-lysosomal system under wide range of stressors they can serve as extracellular markers of functionality of these organelles.

Key words: free oligosaccharides (FOS), HPLC-profiles of glycans, ER stress, ER-associated protein degradation (ERAD), endosomal-lysosomal disturbances, glycomarkers.

$\mathrm{T}$ he multilayered protein quality assurance system encompasses almost all cellular organelles, a network of biochemical processes and a multiplex of intracellular and extracellular signaling cascades [1-5]. At the centre of this wide cellular landscape there are two main hubs - the endoplasmic reticulum (ER) and lysosomal-endosomal system. The former is responsible for quality-reliable guarantee of newly synthesized proteins, the latter for effective degradation of mature proteins, incorrectly folded proteins and their adducts.

The endoplasmic reticulum provides an interconnected space for translation, co-translational and post-translational modifications, folding and assembling of secreted, organelle-targeted and membrane proteins. Only properly folded and assembled proteins can be transported out of the ER via the Golgi apparatus and cytosol to the endpoint of their functional actions - cellular organelles, plasma membrane and extracellular space. Native protein conformation is achieved due to unique environment of the ER lumen and a specific co-translational modification of proteins - N-glycosylation. The oxidation/ reductive conditions of the ER lumen ensure the formation of disulfide bonds maintaining the tertiary and quaternary structure of proteins. The high level of functional chaperone proteins in the ER facilitates protein folding. The high $\mathrm{Ca}^{2+}$ concentration in the lumen is essential for $\mathrm{Ca}^{2+}$-dependent chaperonesprotein interactions. Any disturbance of these three determinants can lead to protein unfolding or misfolding [6].

Cells monitor protein folding by a protein quality control (QC) system is inbuilt in the ER and

(C) 2017 Pismenetskaya I. U., Butters T. D. This is an open-access article distributed under the terms of the Creative Commons Attribution License, which permits unrestricted use, distribution, and reproduction in any medium, provided the original author and source are credited. 
the Golgi apparatus to maintain a balance between protein-folding capacity and protein-folding load, since a significant fraction of newly synthesized proteins in the ER fails to achieve a native conformation. QC distinguishes unfolded or misfolded proteins and sends them to a repeated folding cycle or selects terminally aberrant molecules for endoplasmic reticulum-associated degradation (ERAD) [7].

Excessive accumulation of proteins that are incorrectly conformed in the ER lumen causes ER stress. To guarantee the fidelity of ER functions, cells adjust QC system with a cascade of reactions a specialised signaling network termed the unfolded protein response (UPR). Unfolded protein accumulation triggers immunoglobulin binding protein/glucose regulated protein-78 (BiP/GRP78) to dissociate from UPR sensors. UPR is mediated by three ER transmembrane sensors - receptors: activating transcription factor 6 (ATF6), inositol reguiring kinase 1 (IRE1) and double-stranded RNA-activated protein kinase (PKR) - like endoplasmatic reticulum kinase (PERK) [8]. To cope with accumulation of misfolded proteins these receptors trigger overlapping cascades of reactions: adaptation, alarm and apoptosis. During adaptation UPR strives to restore ER homeostasis, in particular through an attenuation of global translation and an activation of ERAD, which exports the aberrant proteins from the ER back into the cytosol, where they are degraded by the ubiquitin-proteasome system. When adaptation of cells is unsuccessful, new signals are generated by the ER to induce cell death [9].

Protein N-glycosylation and processing in the ER are directly involved in protein folding, QC system, and ERAD. N-glycosylation is initiated by bloc transfer of precursor oligosaccharide $\mathrm{Glc}_{3} \mathrm{Man}_{9} \mathrm{GlcNAc}_{2}$ to the Asn residue of a nascent polypeptide. After subsequent trimming of two residues of glucose, monoglucosylated oligosaccharide GlcMan $_{9}$ GlcNAc $_{2}$ is recognized by lectin-like ER chaperones calnexin and calreticulin to facilitate protein folding. Cleavage of the last glucose residue gives rise to glycan $\mathrm{Man}_{9} \mathrm{GlcNAc}_{2}$ on a native polypeptide and releases it from calnexin/calreticulin cycle, while an incompletely folded conformer is reglucosylated to allow additional folding cycles. Terminally misfolded glycoproteins are subjected to mannose cleavage (until $\mathrm{Man}_{6-8} \mathrm{GlcNAc}_{2}$ ) and ERAD [10]. By this way some specific glycans-markers or glycocodes are formed to determine glycoprotein fate $[11,12]$.
The early stages of N-glycosylation at both sides of the ER membrane, producing the precursor of oligosaccharides $\mathrm{Glc}_{3} \mathrm{Man}_{9} \mathrm{GlcNAc}_{2}$, and ERAD, destroying newly synthesized misfolded or nonassembled proteins, generate free oligosaccharides (FOS) - unbound structural analogues of glycans of glycoconjugates, their biosynthetic precursors and products of degradation. FOS appear also in lysosomal-endosomal system during degradation of mature glycoconjugates. The details of their formation in cells and precise structures from each source are well-known. FOS are also indentified in biological fluids [13]. Investigations of FOS in biological fluids have shown that their fractions specifically change in different diseases [14-16]. As FOS are generated by the ER and lysosomal-endosomal system, they might be able to reflect the functional status of these organelles.

This work is devoted to specific glycocodes generated by the ER and endosomal-lysosomal system in the form of FOS to provide extracellular signals about their status and demands in health, aging and diseases.

\section{Materials and Methods}

Plasma samples of practically healthy donors, patients with acute myeloproliferative neoplasms, patients suffering from cardiovascular disease were collected in SI Dnepropetrovsk Medical Academy. Plasma samples of healthy volunteers were obtained in the Glycobiology Institute of Oxford University. All the specimens were captured in accordance with the requirements of the relevant Ethics Committees.

Plasma deproteinization and purification. Native plasma was precipitated with $10 \%$ trichloracetic acid (TCA) and centrifuged for $10 \mathrm{~min}$ at $3000 \mathrm{~g}$ to deproteinize, partially sterilize, and stabilize before transportation without lyophilisation. The further purification comprised filtration through a syringe with Millex-LH, $0.45 \mu \mathrm{m}$, filter (Millipore Corp., USA) or Amicon Ultra-0.5 ml Centrifugal Filter Devices (Millipore Corp., USA) to remove remaining protein, according to Alonzi et al. [17].

Porous graphitized carbon chromatography. After deproteinization, monosaccharides (mostly glucose) were removed using porous graphitized carbon (PGC from Thermo Electron, Runcorn, UK) chromatography with the column for $1 \mathrm{ml}$ (25 $\mathrm{mg} / \mathrm{ml}$ ) according to the laboratory's protocol. The column was pre-equilibrated twice with $1 \mathrm{ml}$ of methanol, then twice with $1 \mathrm{ml}$ of Milli- $\mathrm{Q}^{\mathrm{TM}}$ 
$\mathrm{H}_{2} \mathrm{O}$, twice with $1 \mathrm{ml}$ of acetonitrile with $0.1 \%$ TFA (trifluoroacetic acid) and again twice with $1 \mathrm{ml}$ of Milli-Q ${ }^{\mathrm{TM}} \mathrm{H}_{2} \mathrm{O}$. A sample $(1.5 \mathrm{ml})$ obtained after filtration through Millax ${ }^{\circledR}-\mathrm{LH} 0.45 \mu \mathrm{m}$ filter, was applied to the column and washed with $2 \mathrm{ml}$ of Milli$\mathrm{Q}^{\mathrm{TM}} \mathrm{H}_{2} \mathrm{O}$. Oligosaccharides were eluted with $2 \mathrm{ml}$ of $0.1 \%$ TFA in acetonitrile-water mixture $(1: 1 \mathrm{v} / \mathrm{v})$. To change the solvent, the mixture was dried with a rotary concentrator EYELA Vapour (Tokyo Rikakikai Co., LTD, Japan) and then with vacuum concentrator SPD SpeedVac (Thermo Scientific, USA).

Fluorescent labelling with 2-anthranilic acid $(2-A A)$. Free carbohydrates were labelled with anthranilic acid (Sigma - Poole, Dorset, UK) as described by Neville D.C.A. et al. [18]. Anthranilic acid $(30 \mathrm{mg} / \mathrm{ml})$ was dissolved in a mixture of $4 \%$ $(\mathrm{w} / \mathrm{v})$ trihydrate sodium acetate and $2 \%(\mathrm{w} / \mathrm{v})$ of boric acid in methanol, $45 \mathrm{mg}$ of sodium cyanoborohydride were added and thoroughly mixed. This mixture was used as a labelling solution. Milli- $\mathrm{Q}^{\mathrm{TM}}$ $\mathrm{H}_{2} \mathrm{O}(30 \mu \mathrm{l})$ and $80 \mu \mathrm{l}$ of the labelling solution were added to a sample dried in SpeedVac concentrator, stirred carefully and the reaction was carried out for $1 \mathrm{~h}$ at $80^{\circ} \mathrm{C}$. The tube was cooled at room temperature and $1 \mathrm{ml}$ of acetonitrile-water mixture (97:3, $\mathrm{v} / \mathrm{v})$ added.

Removal of noncarbohydrate contaminants and unconjugated fluorescent dye. For purification after 2-AA labelling, a column Spe-ed SPE Cartridges Amide-2 (Applied Separations, USA) was used. Samples were loaded in $1 \mathrm{ml}$ of acetonitrile-water mixture $(97: 3, \mathrm{v} / \mathrm{v})$ using gravity flow and allowed to drip through the column. The column was washed twice with $1 \mathrm{ml}$ of acetonitrile-water mixture (95:5, $\mathrm{v} / \mathrm{v})$. The labelled oligosaccharides were eluted twice with $0.75 \mathrm{ml}$ of Milli-Q ${ }^{\mathrm{TM}}$ water and stored at $-20^{\circ} \mathrm{C}$ [17].

Anion-Exchange Separation of 2-AA labelled neutral and charged oligosaccharides. 2-AA labelled sugars were separated into neutral and charged glycans with QAE-Sephadex (Q25-120) chromatography[18]. QAE-Sephadex A-25 (acetate form, $200 \mu \mathrm{l}$ ) was placed in a $1.0 \mathrm{ml}$ empty solidphase extraction (SPE) column (Applied Separations, USA). The column was pre-washed twice with $1 \mathrm{ml}$ of Milli-Q ${ }^{\mathrm{TM}}$ water and the 2-AA labelled sample was applied. The column was washed twice with $1 \mathrm{ml}$ of Milli-Q ${ }^{\mathrm{TM}}$ water. Neutral sugars were eluted twice with $1 \mathrm{ml}$ of $0.5 \mathrm{M}$ acetic acid, and anionic sugars were eluted twice with $1 \mathrm{ml}$ of $0.5 \mathrm{M}$ ammonium acetate. 2-AA labelled neutral oligosaccharides were dried using a vacuum centrifuge EYELA Vapour (Tokyo Rikakikai Co., LTD, Japan). After resuspending in $250 \mu \mathrm{l}$ of Milli- $\mathrm{Q}^{\mathrm{TM}}$ water and adding $250 \mu \mathrm{l}$ of $\mathrm{MeOH}, 2-\mathrm{AA}$ labelled neutral oligosaccharides were dried using SPD SpeedVac Concentrator (Thermo Scientific, USA) to remove acetic acid. The 2-AA labelled charged oligosaccharides were frozen with dry ice and lyophilized to remove ammonium acetate. Glycans of each fractions were resuspended in $100 \mu 1$ of Milli- $\mathrm{Q}^{\mathrm{TM}}$ water.

Digestion with sialidase. In order to investigate structures of the charged fraction, glycans of the fraction were digested with sialidase (Artrobacter ureafaciens, OGS, UK) in accordance with the company's instructions. 2-AA labelled glycans $(100 \mu 1)$ were dried in a vacuum concentrater SPD SpeedVac (Thermo Scientific, USA) and resuspended in $5 \mu 1$ of appropriate buffer, then $5 \mu 1$ of sialidase were added and the mixture was incubated at $37^{\circ} \mathrm{C}$ for no less than $18 \mathrm{~h}$. Glycan purification after the digestion was carried out using centrifugation through a Microcon column with Amicon®Ultra $0.5 \mathrm{ml}$ Centrifugal Filter (Millipore, USA). The Microcon column was prewashed with $100 \mathrm{ml}$ of Milli-Q ${ }^{\mathrm{TM}} \mathrm{H}_{2} \mathrm{O}$, centrifuged for $10 \mathrm{~min}$ at $15000 \mathrm{~g}$ and removed into a clean tube. $90 \mu \mathrm{l}$ of Milli- $\mathrm{Q}^{\mathrm{TM}} \mathrm{H}_{2} \mathrm{O}$ were added to the mixture of glycans with sialidase. The solution obtained was loaded into the Microcon column, centrifuged for $10 \mathrm{~min}$ at $15000 \mathrm{~g}$ and washed with $100 \mu \mathrm{l}$ of Milli$\mathrm{Q}^{\mathrm{TM}} \mathrm{H}_{2} \mathrm{O}$ by centrifugation as above. The centrifugate was collected, dried with a vacuum concentrater, and then resuspended in $100 \mu \mathrm{l}$ of Milli-Q ${ }^{\mathrm{TM}}$ $\mathrm{H}_{2} \mathrm{O}$.

2-AA labelled FOS from transferrin were used as an external standard for structural decoding.

High-Performance Liquid Chromatography (HPLC). Free oligosaccharides were analysed using HPLC after 2-AA labelling as described [18, 19]. The chromatography system consisted of a Waters Alliance 2695 Separations Module (USA) with the column $4.6 \times 250 \mathrm{~mm}$ TSK gel-Amide 80 (Anachem, Luton, Beds, UK) and in-line Waters 474 Fluorescence Detector (USA) set at $\lambda_{\mathrm{ex}} 360 \mathrm{~nm}$ and $\lambda_{\mathrm{em}}$ $425 \mathrm{~nm}$.

Glucose unit (GU) values were determined following comparison with a 2-AA labelled glucose oligomer ladder derived from a partial hydrolysate of dextran as an external standard. The data were collected and processed using Empower software.

To collect chromatographic data and process them computer programs Waters Millennium, Waters Empower, Peak Time, Microsoft Office Excel 
2003/2007, Microsoft Power Point 2003/2007 were used.

\section{Results and Discussion}

Our investigation of serum FOS from healthy donors revealed that concentrations of these molecules are very low, measured in several nanomoles per $\mathrm{ml}$ and differed quantitatively in each specimen. However, HPLC-profiles of these FOS unexpectedly appeared to be quite stable with high qualitative reproducibility from sample to sample [20]. Fig. 1 (II) represents HPLC-profile of serum FOS of healthy donors in correspondent time interval from 20 to $44 \mathrm{~min}$ to show free oligosaccharides consisting of 4 and more monosaccharide residues (the lower scale on the chromatogram). A comparison with an external standard - the partially hydrolyzed dextran that can be seen in dotted lines on the chromatogram - allowed molecular weight calculation of each species in glucose units (GU, the upper scale) and then matching them up with the intracellular FOS which structures were well-known. Among intracellular FOS specified before [17], 11 glucosylated or non-glucosylated high-mannose counterparts $\left(\mathrm{Glc}_{0-3} \mathrm{Man}_{3-9} \mathrm{GlcNAc}_{1-2}\right)$ were found for 12 identified serum species and subspecies. There was no identified counterpart for the only species - the second peak. Separation of the total pool of FOS (Fig. 1, IIA) into neutral (Fig. 1, IIB) and charged (Fig. 1, IIC) fractions showed that most species $(92.84 \pm 0.15 \%)$ belonged to uncharged glycans. The main species determining the shape of the whole chromatogram were the following: 2 - with unknown structure, 4-Man ${ }_{4}$ GlcNAc$_{1}$, 6-Man GlcNAc $_{1(2)}, 7-\mathrm{Glc}_{1} \mathrm{Man}_{5} \mathrm{GlcNAc}_{1(2)}$.

Detailed analysis of the neutral fraction and comparison of its glycans with those from different intracellular sources (Fig. 1, I) showed that they were authentic to cytosolic (Fig. 1, IA) or intraluminal (Fig. 1, IC) FOS from the dolichol phosphate cycle, and ERAD of glycans or glycoproteins (Fig. 1, IB). Thus, glycan Man ${ }_{4}$ GlcNAc$_{1}$ is generated on the cytosolic side of the ER membrane. Glycan Man $_{5}$ GlcNAc $_{1}$ can appear from the cytosolic part of the dolichol phosphate cycle and both branches of ERAD. Glucosylated glycan Glc $\mathrm{Man}_{5} \mathrm{GlcNAc}_{1}$ can be released only by ERAD. Some neutral species can also be generated by lysosome (Fig. 1, III) but their contribution is not more than $7-8 \%$, taking into account digest effectiveness of lysosomal-endosomal system with regard to charged glycans.
Analysis of the charged fraction revealed the presence of several species $(1,2,3,5,6 \mathrm{~b}, 10 \mathrm{a})$ in low concentration (Fig. 1, IIC). Digestion of the charged glycans with sialidase and matching them up with external standards - oligosaccharides from transferrin with known structures - allowed us to define sialic acid-bearing species and decipher the structure of 10a that appeared to be a complex type N-glycan with two residues of sialic acid $\left(\mathrm{Sia}_{2} \mathrm{Gal}_{2} \mathrm{GlcNAc}_{2} \mathrm{Man}_{3} \mathrm{GlcNAc}_{2}\right.$ ). The most probable sources of these intracellular FOS derived from serum samples are the lysosomes and endosomes that are involved in glycoconjugate digestion.

Our results show that, serum-derived neutral FOS appeared to originate mostly from ER and therefore points to ER functional or dysfunctional status. Serum-derived charged FOS might be generated by the lysosomal-endosomal system and could reflect physiological changes. To verify the idea that serum free oligosaccharides can serve as biomarkers of functionality of intracellular organelles, we performed assays on native models - human healthy aging, acute myeloproliferative neoplasms, and cardiovascular diseases.

Human healthy aging. Serum FOS of healthy volunteers at the age of 22-25-year old and those of healthy donors at the age of 46-52-year old (described above) were compared to evaluate sensitivity of HPLC-profiles of serum free oligosaccharides to aging changes inside the ER and lysosomal-endosomal system.

There were 10 species identified in HPLC-profiles of serum FOS pool of healthy donors (Fig. 2, I). All the species have the same GU as their analogues in the second group (Fig. 2, III) and are marked with the same numbers on the chromatograms. Of these, 9 were structural counterparts $\left(\mathrm{Glc}_{0-3} \mathrm{Man}_{3-9} \mathrm{GlcNAc}_{1-2}\right)$ of the intracellular high-mannose FOS as deciphered before [17]. As in the case of serum FOS from healthy volunteers the second peak was structurally distinct from recognised intracellular FOS.

Separation of the total pool of FOS (Fig. 2, IIA) into neutral (Fig. 2, IIB) and charged (Fig. 2, IIC) fractions revealed that like in the case of serum FOS of practically healthy donors (Fig. 2, IIIB) most of the species of HPLC-profiles were uncharged glycans. But unlike FOS of practically healthy donors, the main species were: $4-\mathrm{Man}_{4} \mathrm{GlcNAc}_{1}$, 6- $\mathrm{Man}_{5} \mathrm{GlcNAc}_{1(2)}, \quad 7-\mathrm{Glc}_{1} \mathrm{Man}_{5} \mathrm{GlcNAc}_{1(2)}$, $8-\mathrm{Man}_{6} \mathrm{GlcNAc}_{1(2)}$ or/and $\mathrm{Glc}_{3} \mathrm{Man}_{4} \mathrm{GlcNAc}_{1}$. The charged serum FOS of healthy volunteers 


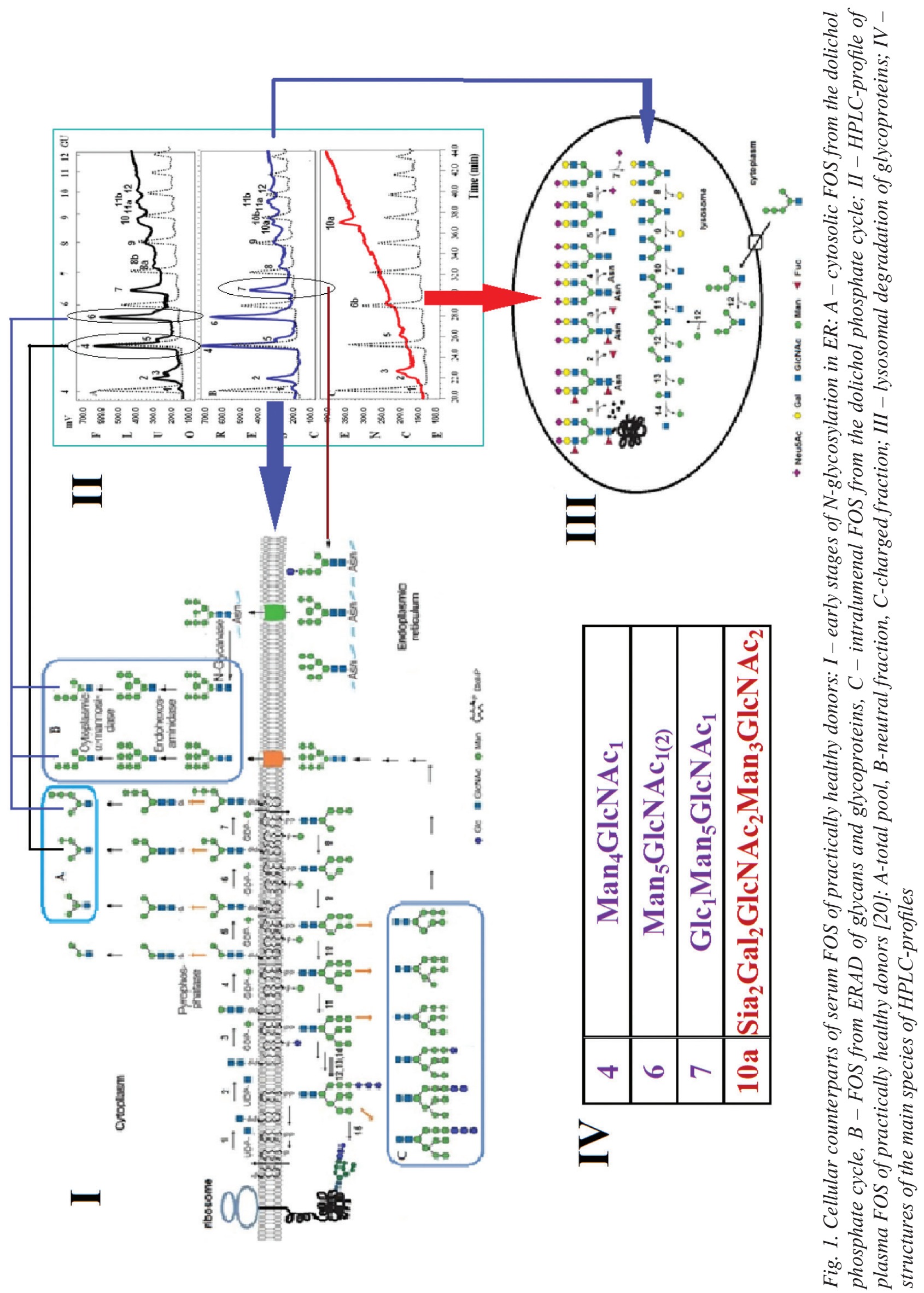




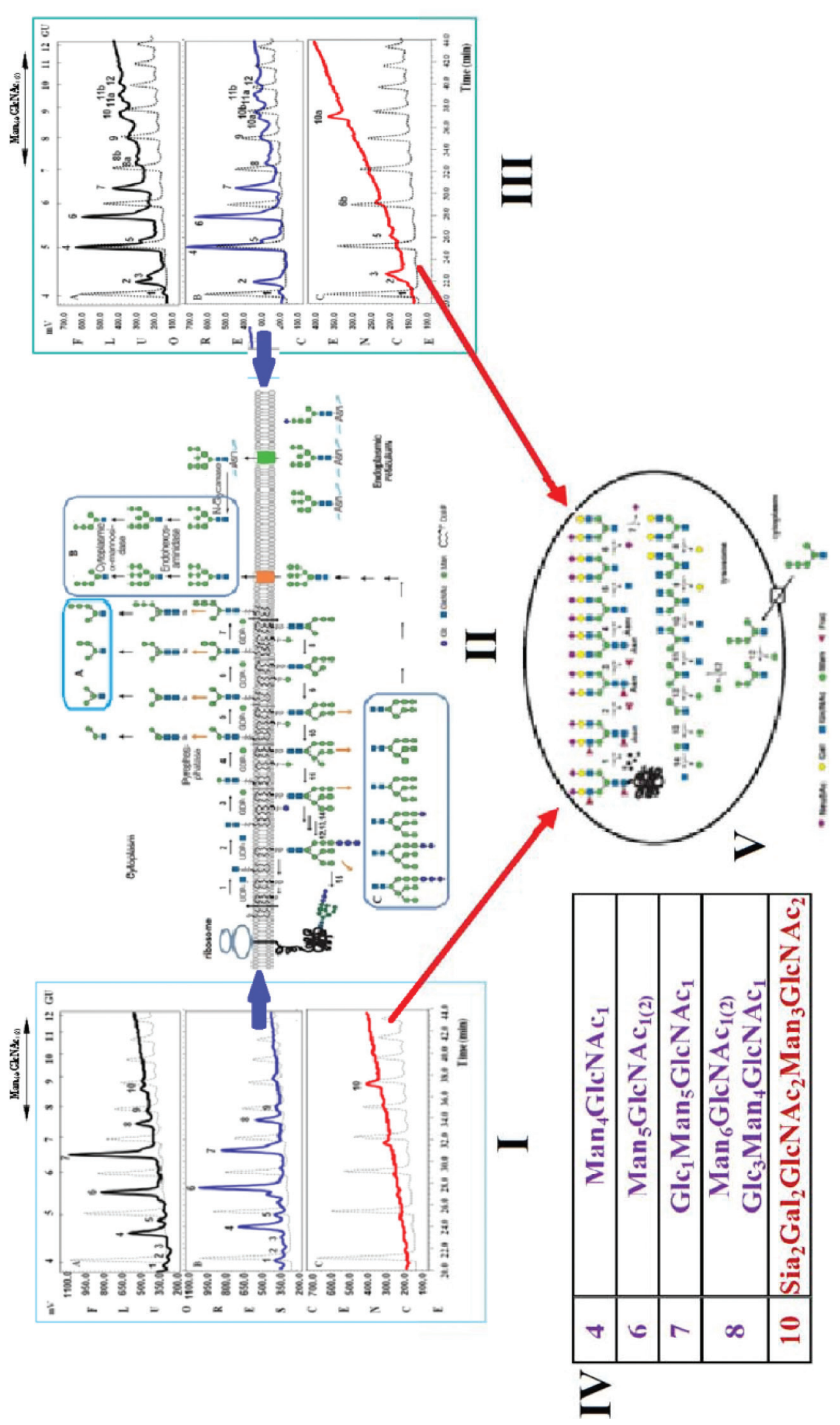

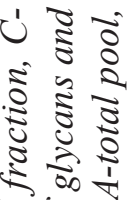

$\overline{0}$

密

की

$\ddot{2}$ व

र क

홍

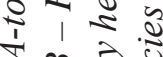

$\therefore \infty \frac{\pi}{2}$

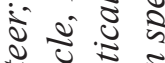

ปิ

๑

3.

इे की

$\approx \sqrt{5} 5$

ค.

$\therefore . \overline{0}$

워

ㄴำ

ปิ

造专

यू के

$x$ II

든

के

1 गे गे

$-1 \approx$

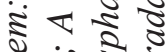

के के

के

๘)

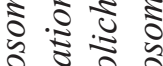

웡

के के च

ठำ

文这

के

$\Rightarrow$ को

ฐ ฐ

저요

इ छे

ปั 1.

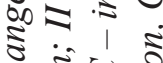

ฮั่

की ड़ जे है

के

$\checkmark$ \&

$\infty \frac{5}{2} \frac{0}{0}$ 
was represented with one species: a complex type $\mathrm{N}$-glycan with two residues of sialic acid $\left(\mathrm{Sia}_{2} \mathrm{Gal}_{2} \mathrm{GlcNAc}_{2} \mathrm{Man}_{3} \mathrm{GlcNAc}_{2}\right.$ ).

Comparison of HPLC-profiles of neutral fractions in both groups with intracellular sources of FOS showed interesting regularities reflecting distinct processes occurring in ER with aging. The peak area of species 4 ( Man $_{4} \mathrm{GlcNAc}_{1}$ ) with respect to a peak area of species 6 (Man $\mathrm{GlcNAc}_{1}$ ) increased in the group of healthy donors in comparison with the group of healthy volunteers (Fig. 2, IB and IIIB). As Man $_{4}$ GlcNAc $_{1}$ is synthesized on the cytosolic side of the ER membrane and must be converted into Man $_{5}$ GlcNAc $_{1}$ during dolichol-mediated glycosylation, an increasing of concentration of free Man $_{4}$ GlcNAc $_{1}$ means that it cannot be transformed into next metabolite with the same rate. This indicates that the dolichol phosphate cycle is less competent with aging. The appearance of FOS with 7 and more mannose residues on the chromatogram of the second group (Fig.2, IIIB), while they are absent on the chromatogram of the first group (Fig. 2, IB) make it clear that ERAD of intralumenal ER glycans and glycoproteins is intensified with aging. Addition of more species (Fig. 2, IIIC) to the main glycan ( $\mathrm{Sia}_{2} \mathrm{Gal}_{2} \mathrm{GlcNAc}_{2} \mathrm{Man}_{3} \mathrm{GlcNAc}_{2}$ ) of the charged fraction (Fig. 2, IC) demonstrates an aging-induced perturbation in lysosomal-endosomal system.

Acute myeloproliferative neoplasms. Serum FOS of patients suffering from acute lymphoblastic leukemia, acute myelomonocytic leukemia, and acute phase of preleukemic syndrome were analyzed.

In acute oncotransformation of bone marrow cells chromatographic spectra of serum FOS had some individual features, but common ones were much more pronounced. There were only 5 main species identified in HPLC-profiles of serum FOS pool: 6, 7, 8, 9 and 10a (Fig. 3, IA). The first two species (6 and 7) had very low concentrations, and in some samples 7 was not identified at all.

Separation of the total pool of FOS (Fig. 3, IA) into neutral (Fig. 3, IIB) and charged (Fig. 3, IIC) fractions revealed that in neutral fraction the only species identified were: 6-Man $\mathrm{GlcNAc}_{1(2)}$, 7-Glc Man $_{5}$ GlcNAc $_{1(2)}$, 8-Man GlcNAc $_{1(2)}$ or/and $\mathrm{Glc}_{3} \mathrm{Man}_{4} \mathrm{GlcNAc}_{1}$, 9-Man $\mathrm{GlcNAc}_{1(2)}$. Charged serum FOS were represented with 2 main species: 9 a complex type $\mathrm{N}$-glycan with one residue of sialic acid ( Sia $_{1}$ Gal $_{2}$ GlcNAc $_{2}$ Man $_{3}$ GlcNAc $_{2}$ ) and 10a - a complex type $\mathrm{N}$-glycan with two residues of sialic acid ( $\mathrm{Sia}_{2} \mathrm{Gal}_{2} \mathrm{GlcNAc}_{2} \mathrm{Man}_{3} \mathrm{GlcNAc}_{2}$ ).
Comparison of serum FOS HPLC-profiles of patients suffering from acute myeloproliferative neoplasms with those of healthy donors (Fig. 3, IIIB) showed reduction or even almost complete disappearance of the main species that define HPLC-profiles of healthy donors: 4-Man ${ }_{4}$ GlcNAc$_{1}$, 6-Man ${ }_{5} \mathrm{GlcNAc}_{1(2)}$, 7-Glc $\mathrm{Man}_{5} \mathrm{GlcNAc}_{1(2)}$. At the same time concentrations of two species: 8-Man ${ }_{6}$ GlcNAc $_{1(2)}$ or/and Glc $_{3}$ Man $_{4}$ GlcNAc $_{1}$, 9-Man GlcNAc $_{1(2)}$ were substantially increased.

Analysis of intracellular sources of FOS (see Fig. 3, II, IV) revealed an inhibition of the dolichol phosphate cycle on both sides of the ER membrane and intensification of ERAD in acute myeloproliferative neoplasms. Total depression of protein synthesis indicates activation of PERK branch of UPR, and ERAD activation points at involvement of ATF6 branch [21].

Appearance of the complex type N-glycan with one residue of sialic acid ( $\mathrm{Sia}_{1} \mathrm{Gal}_{2} \mathrm{GlcNAc}_{2} \mathrm{Man}_{3} \mathrm{GlcNAc}_{2}$ ) in the charged fraction of serum FOS in acute myeloproliferative neoplasms can be explained by decreasing the neuraminidase-1 activity and increasing lysosomal exocytosis [22].

Cardiovascular pathologies. Serum FOS of 2 groups of patients suffering from ischemic heart disease and arterial hypertension were analyzed. The patients of the first group had no systolic disturbances, while the patients of the second group combined arterial hypertension and ischemic heart disease with chronic systolic heart failure. All the profiles obtained differed from each other and had their own individual features. Some typical chromatograms are represented on Fig. 4.

HPLC-profiles of serum FOS of the patients included the same 12 species that had been found in the healthy donor's profile, but their ratios were completely different (Fig. 4, I, II, IV, V). In heart diseases the cells are often under such threats as oxidative stress, hypoxia, and glucose deprivation [23]. That is why the deep transformations of FOS profiles in cardiovascular disease had been expected. These transformations were observed both in neutral and charged fractions (Fig. 4, IB and C, IIB and C, IVB and $\mathrm{C}, \mathrm{V} \mathrm{B}$ and $\mathrm{C}$ ).

The transformations depended on the severity of the disease. In the case of ischemic heart disease and arterial hypertention the ratio among $\operatorname{Man}_{4} G_{1 c N A c}, M_{5} \operatorname{GlcNAc}_{1(2)}$, and Glc $_{1} \operatorname{Man}_{5} \operatorname{GlcNAc}_{1}$ (4, 6, and 7 species of neutral 


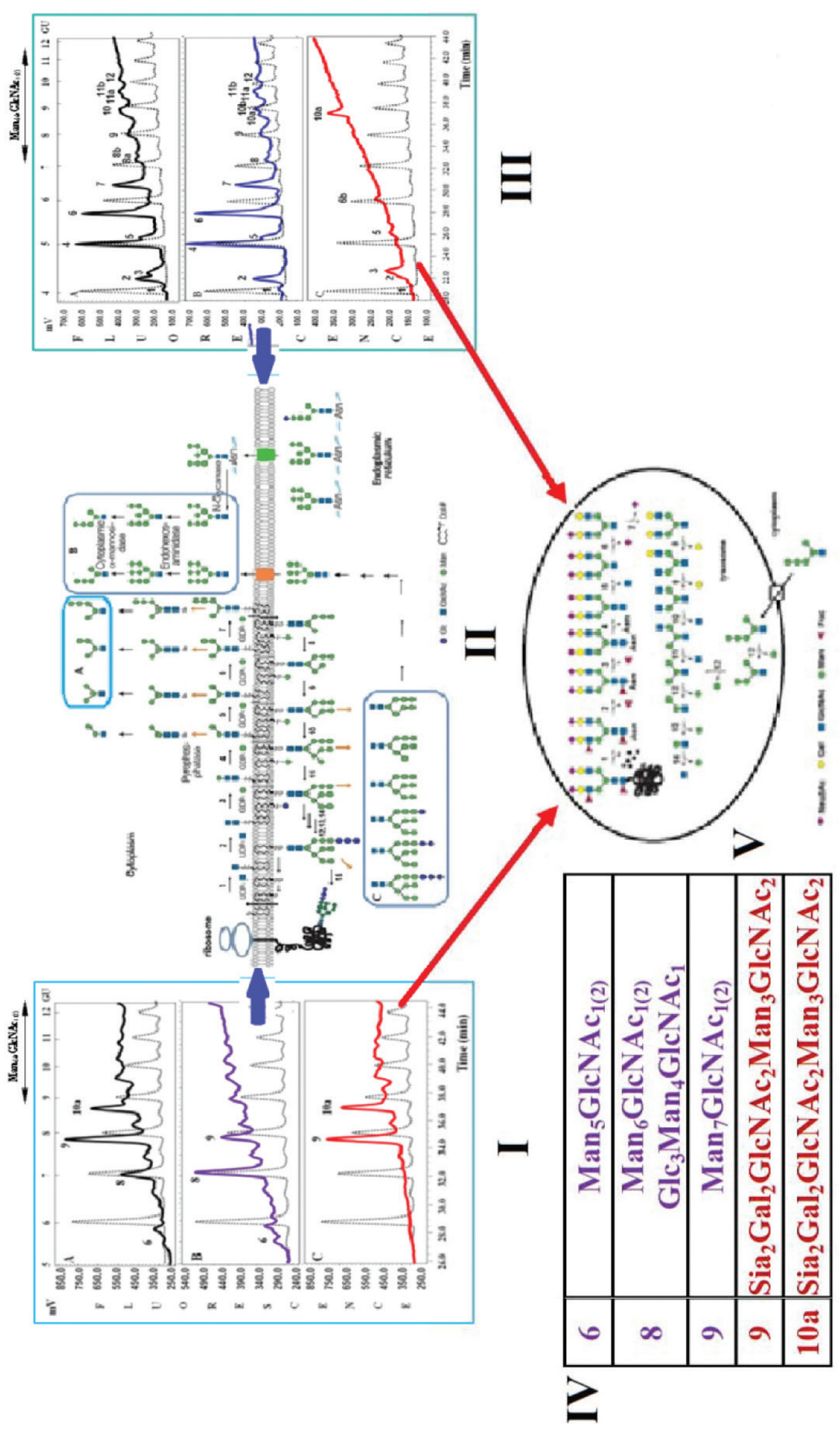

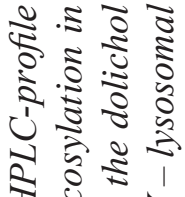

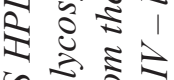

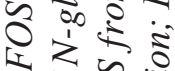

₹ 0 o 0

离

خิ

కิ $1 . \Xi U$

क्ष 1 ह

$\approx \dot{2} \cup \cdot \frac{\pi}{4}$

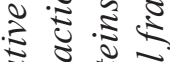

나워

ริ ङ

के छे के

ఏँ

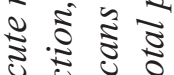

\& 0 क के

त $\overline{0}$

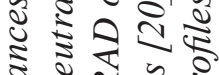

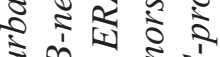

ปั

๘

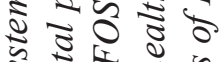

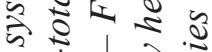

च

है

ङ

ป

इ के $\frac{\pi}{5}$

¿ क :

ㄱ. 궈

๘

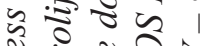

년ㅇำ

ชิ วิ

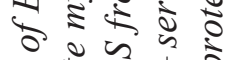

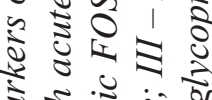

ह $\frac{5}{3} \frac{0}{0}$

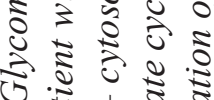

m

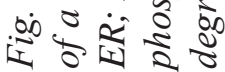




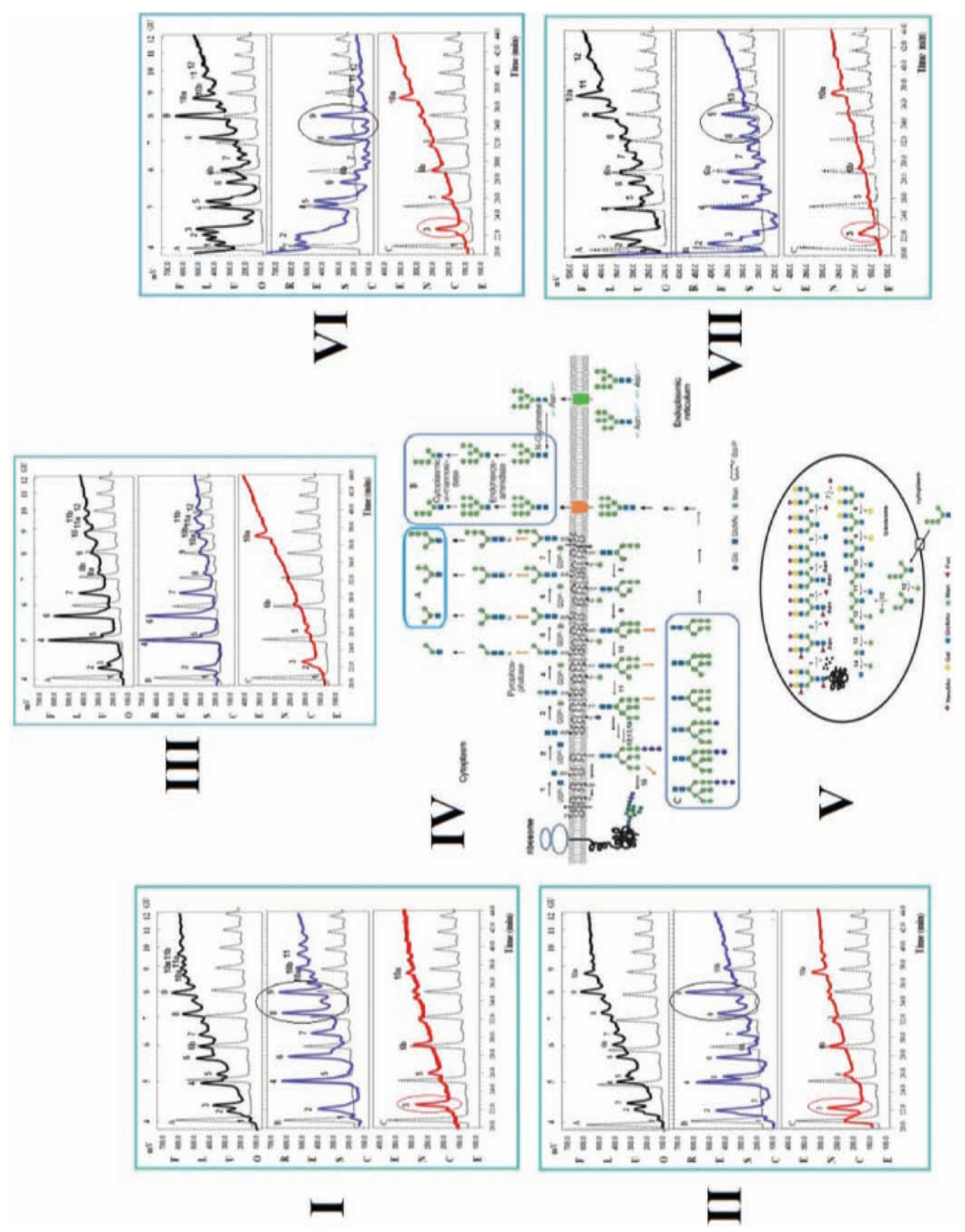

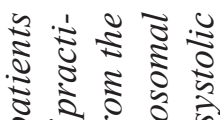

ह रे के के के

o.

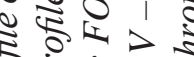

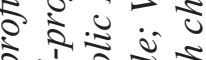

它讨

ఫ

की

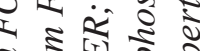

咅离.

๘

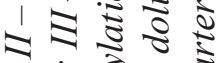

$\therefore \because \bar{~}$

نे

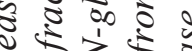

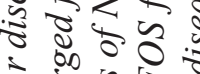

ป

ป ن

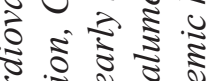

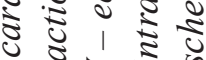

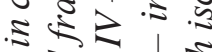

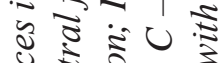

离䓌

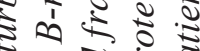

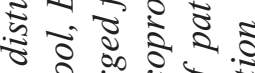

ร ₹

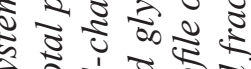

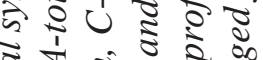

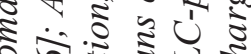

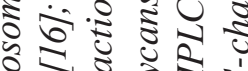

ระ⿻上丨

ป.

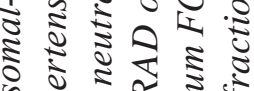

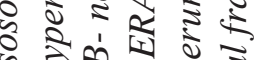
टूरा सी के

సี

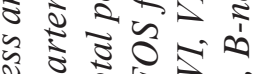

एक ₹

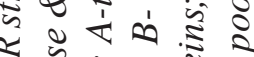

帘

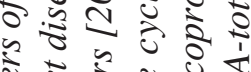

范

ป

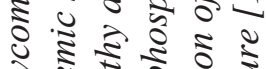

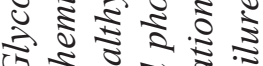

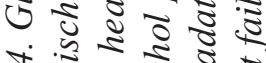

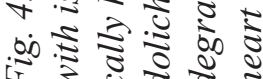


fractions), that are the main species of the control profile, as a rule, remained the same (Fig. 4, IB, IIB).

In the case of chronic heart failure this ratio was not substantiated (Fig. 4, IVB, VB). A set of other changes is connected with substantial enlargement of peak area for 5 and $6 \mathrm{~b}$ species with the structures $\operatorname{Man}_{5} \mathrm{GlcNAc}_{1} / \mathrm{Glc}_{1} \mathrm{Man}_{4} \mathrm{GlcNAc}_{1}$ and $\mathrm{Man}_{4} \mathrm{GlcNAc}_{2}$, respectively.

In spite of great individual differences all the profiles in both groups had some common features. Two main enlarged glycan species in the neutral fraction (8 and 9) and one peak in the charged fraction (3) distinguished the FOS of the patients from those of the practically healthy donors. The neutral marker species appeared to be represented by highmannose glycans Man ${ }_{6} \mathrm{GlcNAc}_{1(2)} / \mathrm{Glc}_{3} \mathrm{Man}_{4} \mathrm{GlcNAc}_{1}$, and $\mathrm{Man}_{7} \mathrm{GlcNAc}_{1(2)}$ (Fig. 4, I, II, IV, V marked in circles). The structure of the 3 of the charged fraction is unknown.

In ischemia and in chronic systolic heart failure all three branches of UPR are known to be activated. IRE- $1 \alpha$ can promote both prosurvival and proapoptotic pathways. ATF6 leads to transcription of ER stress responsive genes (ER chaperones, GRP78), ERAD activation and to cardiomyocyte cell survival. Initially PERK reduces the load on the ER folding machinery, but under prolonged ER stress PERK switches to the promotion of apoptosis and may contribute to heart failure [24, 25].

The transformations of serum FOS HPLC-profiles in cardiovascular disease showed ERAD intensification in all the cases investigated that indicated by an increase of 8 and 9 species in all the samples. It means that ATF6 branch and prosurvival pathways of IRE1 branch are switched on. The FOS HPLCprofiles could not reveal total suppression of protein synthesis by switches between these branches and PERK as the glycan Man GlcNAc$_{1}$ was present in all spectra indicating a continued support of the dolichol phosphate cycle. Our findings are agreed with the idea that progression of a disease depends on dynamics of UPR branches rather than a switch between them [26].

These findings have led us to the conclusions that serum free oligosaccharides being tightly connected to intracellular processes in certain cellular organelles and being able to reflect specifically perturbations in the ER and endosomal-lysosomal system under wide range of stressors can serve as extracellular markers of the ER and endosomal-lysosomal system functionality.
Data on financial support. The experimental part of the research has been done at the laboratory of Dr. Terry D. Butters in the Glycobiology Institute of Oxford University (Oxford, UK) with the financial support of EMBO (ASTF209-2007; ASTF2012010), the International Union Against Cancer (ICR/09/044) and the Oxford Glycobiology Institute.

\section{ГЛІКОМАРКЕРИ СТРЕСУ ЕНДОПЛАЗМАТИЧНОГО РЕТИКУЛУМА І ЛІЗОСОМНО- ЕНДОСОМНОЇ СИСТЕМИ В СИРОВАТЦІ КРОВІ ЛЮДИНИ ПРИ СТАРІННI ТА ЗАХВОРЮВАННЯХ}

\section{I. Ю. Письменецька ${ }^{1}$, Т. Д. Баттерс ${ }^{2}$}

${ }^{1}$ ДУ «Дніпропетровська медична академія», Україна; ${ }^{2}$ CarboNet Consulting Ltd., Оксфорд, Велика Британія; e-mail: ip01589@gmail.com

Для перевірки гіпотези, чи можуть позаклітинні вільні олігосахариди відображати функціональний стан ендоплазматичного ретикулума (ЕР) і ендосомно-лізосомної системи, ВЕРХ-спектри вільних олігосахаридів сироватки крові людини при старінні, гострих мієлопроліферативних новоутвореннях i серцево-судинних патологіях порівнювали iз внутрішньоклітинними гліканами. Після депротеїнізації i очищення вільних олігосахаридів сироватки крові людини їх маркували антраніловою кислотою, поділяли на нейтральні $\mathrm{i}$ заряджені за допомогою хроматографії на QAE сефадексе (Q25-120) i аналізували методом ВЕРХ. Для аналізу гліканів зарядженої фракції їх розщеплювали сіалідазою i порівнювали 3 олігосахаридами трансферину. ВЕРХ-спектри вільних олігосахаридів сироватки крові виявили: за старіння помірне гальмування циклу доліхолфосфату в ЕР, посилення асоційованої з ЕР деградації $\mathrm{i}$ деградації в ендосомно-лізосомній системі; за гострих мієлопроліферативних новоутворень інгібування циклу доліхолфосфату, посилення асоційованої з ЕР деградації і підвищення лізосомального екзоцитозу; у разі серцево-судинних патологій - посилення асоційованої 3 ЕР деградації і деградації глікокон'югатів ендосомно-лізосомною системою. Показано, що вільні олігосахариди сироватки крові виявля- 
ють специфічні зміни ЕР і ендосомно-лізосомної системи за дії широкого спектра стресорних факторів i, певно, можуть бути позаклітинними маркерами функціонального статусу цих органел.

К л юч о в і с ло в а: вільні олігосахариди, ВЕРХ-спектри гліканів, стрес ЕР, асоційована 3 ЕР деградація протеїнів, порушення лізосомноендосомної системи, глікомаркери.

\section{ГЛИКОМАРКЕРЫ СТРЕССА ЭНДОПЛАЗМАТИЧЕСКОГО РЕТИКУЛУМА И ЛИЗОСОМНО- ЭНДОСОМНОЙ СИСТЕМЫ В СЫВОРОТКЕ КРОВИ ЧЕЛОВЕКА ПРИ СТАРЕНИИ И ЗАБОЛЕВАНИЯХ}

\author{
И. Ю. Письменеикая 1 Т. Д. Баттерс ${ }^{2}$ \\ ${ }^{1} Г У$ «Днепропетровская медицинская \\ академия», Украина; \\ ${ }^{2}$ CarboNet Consulting Ltd., Оксфорд, \\ Великобритания; \\ e-mail: ip01589@gmail.com
}

Чтобы проверить гипотезу, могут ли внеклеточные свободные олигосахариды отражать функциональное состояние эндоплазматического ретикулума (ЭР) и эндосомно-лизосомной системы, ВЭЖХ-спектры свободных олигосахаридов сыворотки крови человека при старении, острых миелопролиферативных новообразованиях и сердечно-сосудистых патологиях сравнивали с внутриклеточными гликанами. После депротеинизации и очистки свободных олигосахаридов сыворотки крови человека их метили антраниловой кислотой, разделяли на нейтральные и заряженные с помощью хроматографии на QAE Сефадексе (Q25-120) и анализировали методом ВЭЖХ. Для анализа гликанов заряженной фракции их расщепляли сиалидазой и сравнивали с олигосахаридами трансферрина. ВЭЖХспектры свободных олигосахаридов сыворотки крови выявили: при старении - умеренное торможение цикла долихолфосфата в ЭР, усиление ассоциированной с ЭР деградации и деградации в эндосомно-лизосомной системе; при острых миелопролиферативных новообразованиях - ингибирование цикла долихолфосфата, усиление ассоциированной с ЭР деградации и повышение лизосомального экзоцитоза; при сердечно-сосудистых патологиях - усиление ассоциированной с ЭР деградации и деградации гликоконъюгатов эндосомно-лизосомной системой. Показано, что свободные олигосахариды сыворотки крови выявляют специфические изменения ЭР и эндосомно-лизосомной системы при действии широкого спектра стрессорных факторов, и, вероятно, могут быть внеклеточными маркерами функционального статуса этих органелл.

Ключевые слова: свободные олигосахариды, ВЭЖХ-спектры гликанов, стресс ЭР, ассоциированная с ЭР деградация протеинов, нарушения лизосомно-эндосомной системы, гликомаркеры.

\section{References}

1. Pechmann S, Willmund F, Frydman J. The ribosome as a hub for protein quality control. Mol Cell. 2013; 49(3): 411-421.

2. Gardner RG, Nelson ZW, Gottschling DE. Degradation-mediated protein quality control in the nucleus. Cell. 2005; 120(6): 803-815.

3. Matsuo Y, Kishimoto H, Tanae K, Kitamura K, Katayama S, Kawamukai M. Nuclear protein quality is regulated by the ubiquitin-proteasome system through the activity of Ubc4 and San1 in fission yeast. J Biol Chem. 2011; 286(15): 1377513790.

4. Fischer F, Hamann A, Osiewacz HD. Mitochondrial quality control: an integrated network of pathways. Trends Biochem Sci. 2012; 37(7): 284292.

5. Apaja PM, Lukacs GL. Protein homeostasis at the plasma membrane. Physiology (Bethesda). 2014; 29(4): 265-277.

6. Minamino T, Komuro I, Kitakaze M. Endoplasmic reticulum stress as a therapeutic target in cardiovascular disease. Circ Res. 2010; 107(9): 1071-1082.

7. Ruggiano A, Foresti O, Carvalho P. Quality control: ER-associated degradation: protein quality control and beyond. J Cell Biol. 2014; 204(6): 869-879.

8. Chakrabarti A, Chen AW, Varner JD. A review of the mammalian unfolded protein response. Biotechnol Bioeng. 2011; 108(12): 2777-2793.

9. Thibault $\mathrm{G}$, Ismail $\mathrm{N}, \mathrm{Ng}$ DT. The unfolded protein response supports cellular robustness as a broad-spectrum compensatory pathway. Proc Natl Acad Sci USA. 2011; 108(51): 20597-20602.

10. Glozman R, Okiyoneda T, Mulvihill CM, Rini JM, Barriere H, Lukacs GL. N-glycans 
are direct determinants of CFTR folding and stability in secretory and endocytic membrane traffic. J Cell Biol. 2009; 184(6): 847-862.

11. Gabius HJ, André S, Jiménez-Barbero J, Romero A, Solís D. From lectin structure to functional glycomics: principles of the sugar code. Trends Biochem Sci. 2011; 36(6): 298-313.

12. Sybirna NO, Shevtsova AI, Ushakova GO, Pysmenetska IU. Fundamentals of Glycobiology. Lviv: Ivan Franko National University. 2015; 294-296. (in Ukrainian).

13. Pismenetskaya IU, Butters TD. "Three sources and three component parts" of free oligosaccharides. Ukr Biochem J. 2014; 86(6): 5-17.

14. Pismenetskaya IU, Butters TD. Decoding the structures of plasma free oligosaccharides from patients with chronic myeloproliferative diseases. Lab Diagn. Eastern Europe. 2014; 12(4): 69-78. (in Russian).

15. Pismenetskaya IU, Butters TD. HPLC-profiles of plasma free oligosaccharides in acute hematologic malignancies. Sci Notes of Taurida VI Vernadsky Nat Univ. Series: Biology and Chemistry. 2014; 27(66)(3): 102-111. (In Russian).

16. Pismenetskaya IU, Butters TD. Chromatographic profiles of blood plasma free oligosaccharides in patients with cardiovascular disease. Visnyk Dnipr Univ. Series: Biology and Medicine. 2015; 6(1): 51-56. (In Russian).

17. Alonzi DS, Neville DC, Lachmann RH, Dwek RA, Butters TD. Glucosylated free oligosaccharides are biomarkers of endoplasmic- reticulum alphaglucosidase inhibition. Biochem J. 2008; 409(2): 571-580.

18. Neville DC, Coquard V, Priestman DA, te Vruchte DJ, Sillence DJ, Dwek RA, Platt FM, Butters TD. Analysis of fluorescently labelled glycosphingolipid-derived oligosaccharides following ceramide glycanase digestion and anthranilic acid labelling. Anal Biochem. 2004; 331(2): 275-282.
19. Neville DC, Dwek RA, Butters TD. Development of a single column method for the separation of lipid- and protein-derived oligosaccharides. J Proteome Res. 2009; 8(2): 681-687.

20. Pismenetskaya IU. Butters TD. Blood plasma free oligosaccharides of practically healthy volunteers. Sci Notes Taurida VI Vernadsky Nat Univ. Series: Biology and Chemistry. 2012; 25(64)(1): 182-187. (In Ukrainian).

21. Kharabi Masouleh B, Chevet E, Panse J, Jost E, O'Dwyer M, Bruemmendorf TH, Samali A. Drugging the unfolded protein response in acute leukemias. J Hematol Oncol. 2015; 8: 87.

22. Pismenetskaya IU, Butters TD. Molecular and cellular mechanisms of profile changes of charged blood plasma free oligosaccharides in myeloproliferative disorders. Visnyk Dnipr Univ. Series: Biology and Medicine. 2016; 7(1): 59-64. (In Russian).

23. Liu M, Dudley SC Jr. Role for the Unfolded Protein Response in Heart Disease and Cardiac Arrhythmias. Int J Mol Sci. 2015; 17(1). pii: E52.

24. Thorp EB The Myocardial Unfolded Protein Response during Ischemic Cardiovascular Disease. Biochem Res Int. 2012; 2012: 583170.

25. Gao G, Xie A, Zhang J, Herman AM, Jeong EM, Gu L, Liu M, Yang KC, Kamp TJ, Dudley SC. Unfolded protein response regulates cardiac sodium current in systolic human heart failure. Circ Arrhythm Electrophysiol. 2013; 6(5): 10181024.

26. Walter F, Schmid J, Düssmann H, Concannon CG, Prehn JH. Imaging of single cell responses to ER stress indicates that the relative dynamics of IRE1/XBP1 and PERK/ ATF4 signalling rather than a switch between signalling branches determine cell survival. Cell Death Differ. 2015; 22(9): 1502-1516.

Received 08.11.2016 